\title{
Those Goddamn ointments: Four histories
}

\author{
TOM HATSIS* \\ Co-Director of Psanctum Psychedelia, Portland, OR, USA
}

(Received: July 6, 2019; accepted: August 5, 2019)

\begin{abstract}
A commonly misunderstood area of Western psychedelic history involves psychoactive ointments that have become part of popular lore during the early modern and Renaissance eras. These substances amorphously considered as "flying ointments" have various histories. This paper addresses four separate histories regarding these beliefs: (a) one conveyed in the writings of anthropologist Michael Harner in his Hallucinogens and Shamanism (Harner, 1973); (b) an early modern reconceptualization of witches' ointments history that began 600 years ago as a theological misconstrual of the nature of these magical unguents that fueled popular ideas about witches; (c) a probable historical reality of transvection ointments (referring to their alleged ability to make the person fly in some form) containing powerful tropane alkaloids (henbane, mandrake, and belladonna) that informed other traditions; and (d) a "post modern ointment" derived by contemporary scholars who doubted the reality of any actual flying ointments, instead ascribing them to literary traditions and the product of overworked and fearful religious minds. This article presents the evidence for these varying conceptions that early modern "flying ointments" have taken throughout the centuries and relates them to the broader cultural trends that have shaped these ointments in popular imagination. Careful adjudication of primary and secondary sources suggests that only the transvection ointment had an actual basis in historical fact.
\end{abstract}

Keywords: witchcraft, flying ointment, witches' ointment, transvection ointment

\section{INTRODUCTION}

One commonly misunderstood area of Western psychedelia concerns the psychoactive ointments of the early modern and Renaissance eras. Many may not know that what is often amorphously considered a "flying ointment" exists as four separate histories - as four separate ideas. And while all four arrest interest in their own right, only one of them has a probable grounding in historical reality. I call these four ointments:

1. Harner's flying ointment: this refers to the makeover these ointments received in the writings of anthropologist Michael Harner in his Hallucinogens and Shamanism (Harner, 1973). While I feel Harner was correct in a broad sense - that some people were having somnitheogenic (e.g., "generating divinity in dreams;" Hatsis, 2018) experiences with these ointments - its most famous feature - that of masturbating with a broom saturated in a psychedelic ointment - goes back no further in time than the early 1970s.

2. The witches' ointment: some modern scholars were not the only ones to misunderstand the nature of these powerful ointments. Another ointment history began 600 years ago when theologians misconstrued the nature of these magical unguents in deeply disturbing ways. This is "the witches' ointment," a ghastly goop composed of the flesh of murdered children. The reader will be pleased to know that this ointment was a fabrication. Much of our popular ideas about witches (they are evil, fly on a broom, and keep demon familiars) come from this early modern radical reconceptualization (coupled with Harner's flying ointment).

3. Transvection ointment: this concerns the probable historical reality of the ointments themselves. Said ointments were reported to contain powerful tropane alkaloids culled from Solanaceae plants like henbane, mandrake, and belladonna. Such plants cause disassociation, dry mouth, vertigo, hallucinations or visions (depending on who you ask), eventually ending in a deep, lucid sleep (Atkinson, 1887; Roberts \& Wink, 1998; Stephenson \& Churchill, 1831). While we do not know exactly what different people called them, the common early modern theme of this unguent's power concerns its ability to cause a person to travel in spirit ("transvect"). This is the probable historical ointment (or something like it) from which both early modern authorities and some modern scholars fashioned both the witches' ointment and Harner's flying ointment.

4. The post modern ointment; devised by scholars skeptical of the reality of transvection ointments. The post modernist interpretation holds that the ointments - even the transvection ointments - were "wholly literary" (Letcher, 2007), nothing more than the inventions of overworked and fearful religious minds. It serves as a counterbalance to Harner's concept of a flying ointment.

* Corresponding address: Tom Hatsis; Co-Director of Psanctum Psychedelia, Portland, OR, USA; E-mail: psillytom@gmail.com

This is an open-access article distributed under the terms of the Creative Commons Attribution-NonCommercial 4.0 International License, which permits unrestricted use, distribution, and reproduction in any medium for non-commercial purposes, provided the original author and source are credited, a link to the CC License is provided, and changes - if any - are indicated. 


\section{HARNER'S FLYING OINTMENT}

Harner's flying ointment is a catch-all term I use to describe a creation of modern invention, albeit one based on a probable historical reality, that of the transvection ointment. In this version, "witches" supposedly rubbed psychedelic mixtures on brooms and then masturbated with them. From this lovely scene, some have argued, doth we receive our popular idea of a witch riding on a broom. Pointedly, Harner never tells us exactly why a person would apply a pharmakon in such a roundabout way (and how one would deal with all those splinters). Nor do we get a reason for the experience, journey, trip (call it what you will) in the first place. With Harner's flying ointment, a person masturbates with an ointment-covered broom, which induces a vague sense of flying through the air with neither flight plan nor destination.

The beginning of Harner's flying ointment can be traced back to 1973 with the publication of two books: first, Michael Harrison's The Roots of Witchcraft; and second, Michael Harner's Hallucinogens and Shamanism. It is unclear which Michael developed the idea first, but it has been suggested that Harrison beat Harner to the punch (Letcher, 2007). Both authors treat the topic differently. Harrison remains cautious, only ruminating about the possibilities: "But that [the ointments] were taken, percutaneously, in a water-solution or ointment raises an interesting suggestion in respect of the famous 'Witches' Broomstick" (Harrison, 1973).

He says nothing more on the matter.

Harner is more confident:

The use of a staff or broom was undoubtedly more than a symbolic Freudian act, serving as an applicator for the atropine-containing plant to the sensitive vaginal membranes as well as providing the suggestion of riding on a steed, a typical illusion of the witches' ride to the Sabbat. (Harner, 1973)

Harner bases this claim on two statements found in early modern records. The first comes from Dominican witch theorist Giordano de Bergamo in his Quaestio de Striges (Inquiry into Witches, c. 1465): “(W)itches confess that on certain days or nights they anoint a staff and ride it to the appointed place or anoint themselves under the arms and in other hairy places (italics mine)" (Hansen, 1901). But this is not the totality of the quote. The full quote reads: "... or they [push the ointment] under their nails, the mouth, ear, or under their hairy areas or underarms" (Hansen (1901, p. 199) “... vulgares communiter tenet, immo et ipse strige fatentur ... certa unctione inungunt baculum ... puta sub unguibus vel in ore aut in aure vel sub capillis aut sub brachiis ... quod totum fit virtute demonis."). The problem here is twofold: first, Harner left out all the other non-masturbatory human crevices (nails, mouth, and ear) in which witches were said to apply the ointment. Second, Bergamo never says that "witches" masturbated with the staffs in the first place, which is right in line with all the evidence. When we look back into the annals of witchcraft we see a variety of ways these ointments were applied, but none of them involve masturbating with brooms or any other domestic tool. In most cases, the ointment was rubbed only onto the flying implement (broom, rake, shovel, and chair), and not the person's body (Cohn, 2000; Keickhefer, 1976; Levack, 2016). Moreover, those few records that mention brooms do not mention vaginal insertion at all (Hansen, 1901). In the even fewer (and earliest) records that address epidermal ingestion of the ointments the vaginal regions are not mentioned; instead, we find the "witch" rubbing the ointment only on the extremities (Jansen, Drell, \& Andrews, 2009; Hansen, 1901). Still in other cases, people supposedly rubbed the ointment on both their bodies and also on the flying apparatus (Wright, 2012). In the one other instance (besides Bergamo) that mentions ointment insertion into the lower cavities, the "witch" uses her fingers, and it is uncertain whether she refers to her vagina or rectum (Pico della Mirandola, 1523, Dialogus Strix, Book II). In zero instances does masturbating with a broom come up in any deposition, confession, court document, or demonology tract. Moreover, accused witches were also said to ride on benches, chairs, and stoves (Hansen, 1901) - should we imagine that they oiled up and masturbated with these objects as well? Furthermore, early records also indicate that a common mode of witches' flight was "super stecore muli et equi" ("on top of mule or horse turds") (Hansen, 1901). Are we to believe that ...?!?! I'll leave it there.

The second example is a little tricky. It concerns the case of Dame Alice Kyteler from 1324, and a rather famous passage that holds the madam using a "pipe of ointment" to "grease a staffe, upon which she ambled and galloped through thick and thin." This quote is often repeated in popular and scholarly literature (Bramshaw, 2009; Gannon, 2013; Hoyt, 1989; Shultes \& Hofmann, 1992). The problem with this passage is that it does not appear anywhere in the original court documents of Dame Alice Kyteler (If there were a reference to Kyterler's "pipe of ointment" it would be found here among the other charges: "In order to arouse love or hatred, or inflict death or disease on a faithful person, [Alice's group] made powders, and ointments, and candles made of fat which were compounded in the following way: with the viscera of cocks sacrificed to demons, detestable vermin, hair, and brains of a dead, unbaptized boy, various herbs like milfoil, and cook these and other abominations, reinforced with incantations, in a pot that was really the skull of a dead man, over a fire" ("... cum araneis et aliis vermibus nigris ad modum scorpionum, cum quadam herba quae dicitur millefolium, et aliis herbis et vermibus detestabilibus una cum cerebro et pannis pueri decedentis sine baptismo in testa capitis cujusdam latronis decollate, ad informationem, dictee Alicise, multas fecit confectiones, pixides, et pulveres, ad affligendum corpora fidelium et amores et odia concitandum, et ut facies quarundam mulierum cum quibusdam incantationibus adjectis apparerent cornutae apud certas personas velut caprae." Wright, p. 32). The first mention of a "pipe of ointment" and "greased staffe" in association with Dame Alice appears 200 years after her trial in Raphael Holinshed's The Chronicle of Ireland (Holinshed, 1587). We see this same false accretion to the original court dossier repeated in an account some 30 years later, as part of the Annales Hiberniae. By this time, Alice's staff even has a name: a "coulter" (Butler, 1842). 
In the 20th century, Egyptologist Margaret Murray (1863-1963) popularized Dame Alice's ointment in her book The Witch-Cult of Western Europe (1921). Only Murray did not check the original trial documents, instead citing Holisnshed's The Chronicles of Ireland (Murray, 1921). And it was from Murray that Harner sourced his example (Harner, 1973). In a somewhat humorous turn of events, Murray had even followed up her citation of The Chronicles of Ireland with a sober note of caution: "Holinshed is not always a reliable authority" (Murray, 1921). Even with this caveat, not a single author since (and including) Murray has bothered to look back to see if Holinshed got it right.

Neither of Harner's examples holds weight. The record from Bergamo was taken out of context and Dame Alice's coulter was a later invention, absent from the original dossier. What began as a small conjectural oversight in Harner's otherwise solid article written some 50 years ago has become fully accepted as popular "fact" today. And it makes sense why: the time and place to introduce such a sexually empowering, psychedelic ointment could not have been better! The post-60s rise of feminism, hot off the trail of the pill and bra-burning generation, readily embraced this new kind of flying ointment (Letcher, 2007). In addition, the late 1960 s and early 1970 s saw not just the rise of free-love and plenty of LSD, but also a "rise of the occult" (Adler, 1986). One English minister, Jacques (1970), lamented, "There is evidence of a growing interest in witchcraft ... and black magic. Free sex ... is being preached with all the enthusiasm of a new religion." A scandalous mix of psychedelics, magic, and matrifocal sexual liberation only meant Harner's flying ointment would be further lathered onto popular culture.

And so it was.

Harner's flying ointment was picked up favorably two decades after its inception by Richard Rudgley in his popular The Alchemy of Culture (Rudgley, 1998). Similarly, Roger Highfield lends the idea credence in The Physics of Christmas (Highfield, 1999), as does Paul Devereux in The Long Trip (Devereux, 2008). In fact, Devereux took this idea to the popular 1998 Channel 4 documentary mini-series, Sacred Weeds, hosted by Oxford archeologist Dr. Andrew Sherratt. And, of course, we find the idea nestled among a host of other childish pretenses that fill Rutajit and Irvin's shallow embarrassment of pseudopsychedelic history, Astrotheology and Shamanism (Irvin \& Rutajit, 2009). Most recently, Cody Johnson, the author of Magic Medicine (2018), revived this "surprisingly salacious" idea in his article "Psychedelics and Witchcraft: The Truth about Hallucinogenic "Hexing Herbs" (Johnson, 2018). Unfortunately, he offers nothing substantial to back the claim. Instead, he cites the same two examples from Harner (Bergamo and the trial of Dame Alice), which have both been misapplied. None of these authors tried to elucidate the underlying, historically contextualized meanings behind the ointments. The focus remains squarely fixed upon sexual innuendo and the Solanaceae plants used.

Although Harner's flying ointment made a huge splash in popular culture, it made little more than a drop of bat's blood in the cauldron of scholarly witch literature and historiography. Conservative historians of the early 1970s rejected the idea out-rightly: both the psychedelic foundation of the ointments in general, and the broomstick applicator hypothesis (Cohn, 2000; Keickhefer, 1976). Even more liberal authors who accepted the psychedelic nature of the ointments found the idea too farfetched. For example, the famed Hans Peter Duerr ignores the broomstick-masturbating in his much lauded Dreamtime (Duerr, 1985). Duerr's work is important as it was the most thorough exposé of transvection ointments at the time - a sound and sober response to both earlier conservative and liberal approaches. Duerr also compared and contrasted European transvection ointments with similar stories from such faraway places like Rhodesia and Normandy Island (South Pacific). Similarly, Homayun Sidky, who dedicates a whole chapter on the use of psychoactive ointments during the early modern and Renaissance periods in his Witchcraft, Lycanthropy, Drugs, and Disease (2010), also says nothing of masturbating with ointment-covered broomsticks. William Monter accepts the reality of transvection ointments (specifically with regards to cases from the Jura region of eastern France), but does not say anything about masturbating with brooms (Monter, 1976). Forensic psychiatrist Jürgen Leo Müller (echoing pharmacologist H. Fühner) shares the idea that "the witches' ointment constituted a means of intoxication and enjoyment for poor people who could not afford more costly pleasures" (Müller, 1998, p. 622). But in his brief exposé of the nightshades used in love potions and transvection ointments, Müller found no grounds for the masturbatory claim. Shultes and Hofmann (1992) say nothing about this in their monumental Plants of the Gods - even as they employ both of Harner's examples, those of Bergamo and Dame Alice. Even Terence McKenna (who can be forgiven for his, at times, charming and impassioned exaggerations), while accepting the historical reality of transvection ointments, says nothing of masturbating with broomsticks (McKenna, 1992). Letcher (2007) dismisses the reality of the ointments altogether in Shroom. Finally, after almost a decade of research and penning the definitive volume on the topic, I found no grounds for masturbating with ointment-covered broomsticks (Hatsis, 2015).

To reiterate: consider the splinters! Ultimately, Harner's flying ointment had two major impacts in the modern world. On the one paw, it unwittingly confused popular ideas regarding these ointments among a public hungry for sensational chum. On the other (and far more importantly), it resurrected a conversation about psychedelic history that had all but fizzled out of cultural consciousness.

\section{THE WITCHES' OINTMENT}

Before Harner's flying ointment, however, there was the "witches' ointment." A witches' ointment is a theologically contrived idea that started to form around the early 1400 s and fully crystallized by the end of that century (Bever, 2008), although the term "witches ointment" would be coined in the mid 1500 s by a physician, Girolamo Cardano (Hatsis, 2015). As it was said to be composed of the flesh and blood of murdered children, the witches' ointment was used by witches to fly to their demonic congregations called Sabbats. At the Sabbat, they would feast on child corpses, 
worship Satan, copulate with demons, dance backward, and plot the overthrow of Christian Europe (Cohn, 2000; Keickhefer, 1976; Russell, 1984). Anything less than this paranoid, theologically manufactured idea is not a witches' ointment.

Such an involved concept did not form overnight. In fact, the witches' ointment was centuries in the making. Let us unpack the various ingredients that formed the above Sabbat scene and lay bare the sinister underpinnings that birthed the theological witches' ointment.

We begin our journey in the ancient world. Sometime around $63 \mathrm{BCE}$ the propraetorian governor of Africa, Catiline, attempted a coup against the Roman State. Years later, the historian Sallust would record that Catiline made his co-conspirators swear a most gruesome oath: "[Catiline] mixed the blood of a man with wine and passed it around in a bowl; when all had uttered the curse and had drunk from the bowl, as is the custom in holy rites, he revealed his plan" (Cohn, 2000, p. 6). Others like Apollodorus of Cassandreia (d. c. $280 \mathrm{BCE}$ ) received similar treatment. Polyaenus recalls that before seizing power, Apollodorus made his allies drink the blood of a sacrificed boy. "[T]hrough this shared pollution," Polyaenus writes, "[Apollodorus] ensured their loyalty" (Cohn, 2000). Now Apollodorus was certainly a tyrant, but it is unlikely that he ever made his cohorts drink sacrificial blood. This same stereotype would later be cast against Rome's newest insurgents in the early 1st and 2nd centuries: a pesky group of former apocalyptic Jews called Christians. As Minucius Felix tells it, these Christians would cover a child in dough, stab it to death, and drink its blood; the act binding them together in Jesus' name (Cohn, 2000).

According to historian Norman Cohn, the examples of Catiline, Apollodorus, and early Christians (and many more like them) constitute a most ancient stereotype: that of the "conspiratorial organization or secret society engaged in a ruthless drive for political power" (Cohn, 2000). For ease and reference, let's call this the "insurgents' stereotype." As Cohn demonstrates in Europe's Inner Demons (2000), historians can trace how the insurgents' stereotype evolved from the ancient world into early modern times - right around the decade (1430s) that the theologically derived witch stereotype began to take shape.

From this new stereotype would be born the witches' ointment.

Once Christianity rose as the dominant power after the fall of Rome, they cast these same aspersions onto groups they deemed heretical throughout the Middle Ages. The insurgents' stereotype would eventually be replaced with the (again for ease and reference) "heretics' stereotype."

We see a rather clear example of how orthodox Christians transferred this stereotype away from themselves and toward "heretical" Christians during a famous case that took place in 1022. That year, a certain knight named Aréfast managed to infiltrate a heretical sect operating in Orléans. The surviving documents of the incident supply us with two facts: first, this particular heretical group employed some kind of psychedelic in their initiatory rites; second, some writers distorted this rite by affixing the insurgents' stereotype to it. Here, we must tease out of the texts what was probably real and what was probably clerical interpolation (Bouquet, 1760).

According to one account written by Paul of St. Père de Chartres, the heretics were said to "ceremonially drink deadly poison" and eat a "heavenly food" that would grant both "angelic visions" and the ability to transvect (" . . erroris venena exitialia propinantem"; " . . coelesti cibo ..."; “ . . visions angelicas ...” Bouquet, 1760, p. 536). Unfortunately, Aréfast ratted out the group; all were arrested not long after, tried, and burned.

Interestingly, after describing how the group was rounded up, arrested, and brought to trial, Paul (or a later editor?) abruptly switches from the third person to the first person: "Before addressing the arbitrations, I would like to reveal how these people confected the heavenly meal to those who do not know." Accordingly, the heretics would gather for a group orgy. Any child born from this union would be tossed onto a fire and burned "after the manner of the ancient pagans." The ashes from the charred corpse would be given as the heavenly food of which "anyone who ... partook only a small portion of it would soon find themselves unable to return to the truth [of orthodox Christianity], as their minds would be aligned with heresy" ("Sed antequam ad conflictum veniamus, de cibo illo, qui caelestis ab illis dicebatur ..."; "ex quo spurcissimo concubitu infans (a) generatus, octava die in medio eorum copioso igne accenso probabatur perignem more antiquorum Paganorum, \& sic in igne cremabatur"; "... unquam postea de eadem haeresi gressum mentis ad viam veritatis dirigere valeret." Bouquet, 1760, p. 538). The document then shifts back to the third person, returning our attention to the heretics in the courtroom.

What are we to make of this? Looking at the full context of the dossier leads me to believe that this one paragraph written in the first person (that is clearly based on the insurgents' stereotype - i.e., "after the manner of ancient pagans") was a later interpolation, and not part of Aréfast's original deposition. The initial account says nothing about how the heavenly food was made - only that it caused "angelic visions." It was Paul (or a later hand) who decided that the heavenly food would conveniently fit into a readily made proscription; as shown, swallowing the remains of dead children belonged to an ancient literary tradition about clandestine conspiracies. Therefore, we cannot take such a claim seriously.

However, the bit about the heavenly food and the angelic visions is not from any literary tradition (pertaining to insurgents or otherwise), but rather belongs to a mystheogenic (e.g., "generating epiphany with psychedelics;" Hatsis, 2018) tradition, giving it an air of authenticity. With the heretics of Orléans, we are witnessing the ancient insurgent stereotype being transferred from pagans and primitive Christians to later medieval Christian heretics.

But Christians would also add some new elements to the stereotype as they hereticized it. First (and rather foully), Christian authors suggested that the child whose flesh and blood were ingested during heretical rituals was born of a most unholy union - an incestuous orgy (Cohn, 2000). Second, Christians added a diabolical element into the scene. Now, the devil (or some form of supernatural entity) would appear from time to time in orthodox descriptions of 
heretical gatherings. Such an idea was perhaps most enthusiastically expressed in Pope Gregory's c. 1230 Vox in Rama (Kors \& Peters, 2001).

By the early 1400 s, this stereotype would again leap from one group to another: from heretic to witch, finding expression in the witches' ointment; this then is the foundation of the child's flesh and blood that was supposedly mixed in them. The long journey from the insurgent stereotype affixed to both pagans and early Christians to the heretical stereotype would finally culminate in the witch stereotype of the early 15 th century.

An anonymous, although influential document, Errores Gazariorum (c. 1438), ties it all together:

The person who has been led astray worships the presiding Devil. The Devil gives the newest heretic an ointment and a stick so as to return to the Sabbat. ... The ointment is made by secret method of diabolical malice, from the flesh of roasted children ... ("Item postquam seductus fecit homagium diabolo presidenti, dat sibi unam pixidem unguento plenam et baculum ceteraque omnia, cum quibus debet seductus ire ad synagogam”; “. . . ungunetum diabolice malignitatis mysterio conficitur ex pinguedine puerorum ...”.) (Hansen, 1901, p. 119)

What makes this document invaluable to our pursuit is the author's use of the word gazarii in the description. It means "Cathars," a "heretical" group that once thrived in Albi, France, but was eradicated by Christian knights during the Albigensian Crusade of the mid 13th century. As it turns out, "Cathar" had become a slander word for a "witch" by the early 15th century (Russell, 1984). The title of this work then more colloquially translates to The Heresy of Witches. Another treatise from the time, titled Errores Valdensium (The Heresy of Waldensian-Witches), asks us to again take note of the name for witches: Valdensium, derived as it is from the heretical group the Waldensians. This text holds that heretical witches flew to their meetings by rubbing a stick with an ointment. Once assembled, each kissed the hindquarters of a demon disguised as a cat as part of their sacred rites (Russell, 1984). People accused of witchcraft would now have this ancient stereotype foisted onto their beliefs and practices - beliefs and practices that had nothing to do with witchcraft at all. Thus, when we read demonology texts that mention these ointments, we are only getting some theologian's insane fantasies. These fantasies formed a literary tradition from which much of the current beliefs about witches derive. The witches' ointment (as theologically constructed) never actually existed. The beliefs regarding witches' ointments evolved out of theological fears over heresy, informed by old beliefs and folk practices.

\section{TRANSVECTION OINTMENTS}

Therefore, if not the more sensational aspects of Harner's flying ointment or the witches' ointment (which together create our modern image of the flying witch), what is true about these psychedelic unguents? We cannot say for certain regarding most claims. And while I have done my best to elucidate the proper account of these ointments, I still admit ignorance in the face of such a dicey history (Hatsis, 2015, 2018). However, I do believe that there is a history beneath those of the witches' ointment and Harner's flying ointment. Sadly most of this history escapes us. The folk uses of these ointments entered the historical record just as theologians began condemning them. For now, I would like to do my best to show what I think was really going on with regard to these goddamn ointments.

Our search circles back to the early 15 th century. We find the first mention of a magical ointment used in such a way that could be misinterpreted as a witches' ointment by an overzealous authoritarian in the 1428 trial record of Italian lay-healer Matteuccia di Francesco (Jansen et al., 2009). Supposedly, she rubbed the ointment over her body, transformed into a mouse, and then called upon a demon who would ferry her to the "Night Doings" at Benevento where it was said others gathered around a walnut tree (note that Matteuccia did not use a broom to fly, nor did she insert one into her vagina.). At the walnut tree, Matteuccia and the others would revere the "Enemy of the Human Race," i.e., Satan. Afterward, the witches would suck the blood out of babies to use in their magic (Jansen et al., 2009).

Except for one aspect (i.e., revering Satan), none of these other attributes (animal transformation, transvecting to Benevento or otherwise, etc.) come from the literary tradition - they come from folk tradition (Levack, 2016; Russell, 1984). And even here, we can see the varnish of the literary tradition pasting over the folk tradition: the idea of transvecting to some kind of supernatural congregation (like Benevento or other places we will meet below) comes from common beliefs. However, the addition of the demons that transported Matteuccia and the others away to Benevento is straight from the learned tradition. This was a regular folk belief with a theological veneer riveted onto it.

Before this time (1428), we hear nothing about transvection ointments in witch trials or demonology literature. And while some have used that fact as a way to argue against the reality of these ointments (Ostling, 2016), they overlook a somewhat obvious and practical point: namely, using these kinds of ointments was not yet considered witchcraft. It was not even considered a secular crime. There was nothing illegal about it. How could it possibly end up in a trial record? It would be like bringing your neighbor to court today for taking a sleeping aid. We, today, in our (thankfully slowly fading) War on Drugs paradigm, have felt that unnecessary Orwellian eye rest upon us. However, all of our evidence seem to indicate that this practice of using an ointment to transvect was undertaken by individuals (with no legal status one way or the other) in the privacy of their homes - except in the few exceptions whence a woman invites someone into her home to witness her feat (Hansen, 1901; Nider, 1475). Furthermore, it seems apparent that until the early 1400s no one cared much about this practice. Even a decade after Matteuccia burned for her deeds not every theologian considered these astral projections via ointments to constitute witchcraft. 
Take Johannes Nider (d. 1438), who gives us a vivid image of a woman rubbing an (apparently heavily soporific) ointment all over her body in both his Predigten (Sermons, c. 1425) and his highly influential Formicarius (The Ant Hill, 1437). As there are some notable similarities and differences between Nider's two writings about this same incident - similarities and differences that will bring us closer to the historical reality of these ointments - I will describe each in turn.

Predigten, the earlier text, contains a collection of sermons Nider had given throughout the 1420s (and possibly earlier; Hansen, 1901). It is written in Old High German, an important detail, as it means that Nider was speaking to a lay audience - commoners - giving us a window into their lives. Traveling preachers, after all, were the "newscasters" of the medieval, early modern, and Renaissance periods (Mormando, 1999). They tended to their audiences' spiritual needs while also reporting on what was happening in both surrounding and faraway villages and cities. The typical tool wielded by traveling preachers was called exempla, or moral stories for good Christians to follow. Usually, exempla are totally made up. However, they do still address real issues (lying, thievery, blasphemy, and yes transvection ointments). As one scholar has noted, it would be counterintuitive to warn people about things they did not think existed (Peters, 1982). Therefore, while the stories themselves were fiction, the issues they addressed were not.

One day Nider gave a sermon on the First Commandment and the implications of idolatry. He used this moment to criticize local women healers, to whom some of his congregants had gone seeking remedies (instead of seeing university-trained physicians). Worse still, these healers' prescriptions had been causing "much trouble" in a community. Nider calls these women "unholda" (sing. "unholden"), a worshiper of the Goddess Holda (Hansen, 1901). I suggest Nider is not talking about one woman in particular, but rather a certain kind of woman - a goddessworshiping healer, perhaps one also knowledgeable in the magical arts.

Besides her frivolous medicines, Nider tells us she also attends nocturnal gatherings at the Heuberg ("Hay Mountain"), a supernatural congregation of sorts - probably a Germanic analog for the walnut tree in Benevento. We do not have many descriptions of the Heuberg from the early 1400 s, but one poem dating to 1410 holds that witches joined heroes of myth and giants on that intriguing mountaintop (Behringer, 2005). And how do the unholden travel? Nider tells us: "salb machent und enweg farent" ("with the salves they make, they fly away") (Hansen, 1901)! He claims that an unholden climbed into a large kneading bowl and sung incantations as she lathered up her flesh with her magical ointment. However, instead of journeying to the Heuberg, she falls into a deep sleep (presumably due to the soporific power of the ointment; Hansen, 1901, p. 437). At no point does Nider claim this woman is an evil character or in league with Satan. The "witch stereotype" is totally absent. And the bit about climbing into a large bowl while chanting and applying the ointment strikes me as so specifically odd, I find it difficult to think Nider simply invented it. Here was no heretical witch who mixed a ghastly ointment made from the flesh and blood of murdered children to fly to the Sabbat, but instead a healer using a psychoactive ointment, perhaps containing opium or a Solanacece (or both) to transvect to the Heuberg. That she intended the ointment to induce in her dreams so lucid that she would believe them to be true also points to the strength of these particular somnitheogens (Hatsis, 2018). To Nider, the unholden was not evil; she was just some person who had deluded herself via some kind of pharmakon.

His warning to his audience is clear: stay away from these kinds of people.

They're nuts.

But Nider was not done ruminating over this strange practice of the unholden.

Now that his congregants had been warned about these kinds of women, he also wanted to tell his learned colleagues. And so years later while writing his penultimate opus Formicarius, he once again brings up this ointment-using, Heuberg-journeying, goddess-worshiping, kind of person. Although, unlike Predigten, written in Old High German, Nider wrote Formicarius in Latin. Therefore, he does not call the woman an "unholden," as his non-Germanic peers would likely not have known what either that, or even the Goddess's name, Holda, meant. Instead, Nider settles on "vetula" ("crazy old woman") for the unholden and "Diana" for Holda (Nider, 1475). Nider also cannot call the unholden's destination the Heuberg (for the same reason - a lack of familiarity with this term in the Latin-writing world); so he says she flew with "Lady Venus," which was an obvious reference to "Venus Mountain" - what learned people called places like the Heuberg (Hatsis, 2015). Of utmost importance, Nider does not retell this story in his chapter "On Witches" in Formicarius, but instead records it in his chapter, "On False Dreams and Revelations," meaning that as late as 1437 one of the most highly influential theologians of his day did not consider it satanic to use magical ointments to transvect to supernatural places.

Just stupid.

Nider's decision to replace Holda's name with Diana was no accident. By the early modern period, "Diana" had become a catch-all term in some Christian and secular literature for the various pagan Goddesses that had survived the fall of Rome and into the rise of Christian Europe (Ginzburg, 1991). We find the pagan Goddess Diana in Christian lore stretching back to the days when Paul the Apostle doggedly spread the message of Christ's resurrection in the mid 1 st century $\mathrm{CE}$. While passing through Ephesus on his way to Macedonia, a mob of locals seized Paul's travel guides, Gaius and Aristarchus. The Ephesians had been riled up by a local silversmith, Demetrius, who feared that conversion from the pagan Gods would mean taking a financial hit on his business; his finely forged statuettes of Diana was his best-selling merchandise. A riot nearly ensued for almost $2 \mathrm{hr}$, as the locals decided what to do with Gaius and Aristarchus. The passions eventually subsided when a clerk suggested that anyone was free to simply take the two captives to court over the matter. Having better things to do with their time, the crowd ultimately dispersed (American Bible Society, 1989).

Diana comes up sporadically through the Middle Ages, always as a way to mock the pagan gods in favor of the 
superiority of the Christian God. Consider this episode from Gregory of Tours (c. 540-600) who encountered a statue worshipped by devotees of Diana in Trier: "I preached always that Diana was nothing, that her images and the worship which they thought it well to observe were nothing; and that the songs which they sang at their cups and wild debauches were disgraceful." He ordered the locals to tie the statue with ropes and pull it down. However, they found that the statue was too strong, and would not budge. Gregory (ever the hero in his own mind) ran into the local church, threw himself to the floor, "and weeping begged the divine mercy that the power of God should destroy that which human energy could not overturn." Then returning to the crowd gathered around the statue, Gregory picked up one of the ropes and pulled. The statue came crumbling down (Brehaut, 1916, p. 195).

Other references to the goddess spring up centuries later. Archdeacon Geoffrey of Monmouth invents a conversation between Brutus of Troy (Britain's fabled first king) and Diana. Brutus wants to know his fate, and where he should set up a temple so "[he] may worship [Diana]." Diana informs him that he should conquer the lands west of Gaul, an area where giants used to live (but had now gone extinct). There, "sons" of "another Troy" would rise. Geoffrey tells this story only so far as to ridicule it: "The Stygian Diana," he writes comparing her to the realm of the dead, "knows ... nothing concerning the future. ... To know the future belongs to God alone" (Major, 1892, p. 4).

For our purposes, Diana's most important appearance in Christian literature presents itself several centuries later in the Canon Episcopi, drafted by Regino of Prüm in 906. Regino had been commissioned by Rathbod of Trier to compose a canon of magical and pagan survivals that both men considered unorthodox. And it would appear that even Gregory's story of victory over Diana in Trier from centuries ago had done little to quell worship of Divine Mothers. Along with criminals and fortune tellers, Regino also mentions "certain wicked women" who believe they can traverse the night with Diana, riding on various animals ("in the silence of the deepest night") "... quod quaedam sceleratae mulieres ..."; "...noctis silentio pertransire ..." (Hansen, 1901, p. 38). It was this image that some theologians would use to demonize the various pagan survivals - some of which included somnitheogenic, transvection ointments.

We have several sourced pictures from history of what this Dianafication of local fertility rites looked like from around the time when some authorities busily debated and formulated the witch stereotype. In Bressanone, 1457, Nicholas of Cusa wrote a sermon that addressed the beliefs of two women from the Fassa Valley who had confessed to him that they followed a "good mistress" named Richella. However, when Nicholas retold this story to his audience, he makes reference to "the society of Diana" - a name that neither woman ever mentioned in their respective confessions (Ginzburg, 1991). Richella would come to the two women riding in a small cart. They would travel to an unspecified location (whether they did so corporally or "in spirit" we do not know), where they would join other revelers. Nicholas remains dubious of the whole idea, and shows these women (what was for that time) leniency: public penance and jail. Indeed, these women could have easily been burned for heresy (Ginzburg, 1991).

We do not have the original court documents of Nicholas's original interrogation of the two women, only his later sermon. Therefore, we do not know if these women used some kind of psychoactive to met Richella. They likely did not, as psychoactives are not necessary for these kinds of experiences (Ginzburg, 1992; Hatsis, 2015).

But they also very well could have. After all, the general concept laid out by the women from the Fassa Valley is not too dissimilar (in a broad sense) from something like the Heuberg or the walnut tree of Benevento: i.e., traveling in spirit. But there are also differences; some of these beliefs entailed joining societies of the dead, while others dealt in the fairy realms.

Take the case of Andrew Mann, who lived around Aberdeen Scotland, tried for witchcraft in 1597. By now, we are almost two centuries passed the formulation of the witch stereotype and its byproduct, the witches' ointment. Mann claimed to be in communication with the "Queen of the Elves." Interestingly (and unusual vis-à-vis mentions of a fairy queen on the continent), a male consort, Chirstonday, who appeared in the form of a stag, accompanied the fairy queen. Mann admitted to having intercourse with the queen, who taught him how to heal his neighbors. Unfortunately for Mann, by this time (the late 16th century), the theological interpretation of these kinds of experiences had already received a diabolical gloss. The judges decided that Mann's actions constituted "plaine witchcraft and devilrie" (Ginzburg, 1991).

We do not know if Mann employed any kind of psychedelic to generate his encounters with the fairies. No account of his claims survives. Nonetheless, some people of his era seemed to believe they could access this realm via a psychedelic pharmakon like mandrake. The Book of Oberon (c. 15th century, Harms, Clark, \& Peterson, 2015) includes an ointment used "to see spirits." Mandrake is used in the recipe, although it is not named specifically; instead, the anonymous author chose to hide the active ingredient of the ointment in a name that only the initiated would understand: herba lucens (i.e., "the herb of light"). Here, an understanding of herbal lore helps us identify the mandrake as the herb of light. Since the days of Josephus (d. c. $100 \mathrm{CE}$ ), mandrake was said to "[send] out a certain ray like lightning" (Whiston, 1737). As late as the 12th century, this lore survived as evidenced by the Harley Manuscript, which states that mandrake "shines at night like a lamp" (BL, 2011). This then is the herba lucens, that timeless psychedelic mandrake, which allowed some early modern psychenauts to enter the realm of the fairies. The minister Robert Kirk (1644-1692) also believed in this fairy realm and called the ability to see it "second sight." Kirk thought that several methods could be employed to achieve second sight. One way - the "more feasible" way - was via a psychoactive ointment (Shaw, 2016).

But a person had to be careful about the context in which they had these experiences. In one instance from 1663, in Vöhringen, Germany, four teenage girls attempted to transvect to a witch dance at the Heuberg by eating a "peculiar piece of bread" (Bever, 2008). We do not know what Magdalena, the supplier of the bread, cooked into the loaf; but 
descriptions of the incident leave no doubt that it contained some kind of psychedelic. In addition, she also claimed to be able to transform into a cow. Whether the animal transformation and the transvection were connected as they were in other instances (Jansen et al., 2009; Henningsen, 1980; Klaniczay \& Pócs, 2005; Wentzel, 1989), or unconnected feats of magic remains unclear based on the little evidence we have regarding the episode. In any event, one of the girls, Margaretha, ended up experiencing what we would call a "bummer." And while we cannot know certainly what Magdalena cooked into the bread, the "two small grains" that she mentioned as included in the recipe upon interrogation might suggest an ergot-infested grain. Indeed, other cases from Scandinavia show more solid evidence for ergot used in witchcraft. A handful of records dating from the 1620 s to 1684 describe the use of black pellets "the size of barley grains" drunk in milk as a way some people "learned witchcraft" (Alm, 2003). Sadly, due to the ties that witchcraft had with psychoactives, witch dances, and harmful magic, the authorities executed Magdalena for veneficium (e.g., "magical poisoning;" Bever, 2008).

Other cases from the Renaissance period tell us even more about the ways ordinary people fit these transvection ointments into common magic and folk beliefs. On January 6, 1631, one Hans Jacob Langen, a troubled young man, awoke in a jail cell in Lauffen, a town in Württemberg, Germany. The wayward Langen had run away from home, desiring the freedom of the road rather than learning a trade. When the authorities asked him how he had ended up in the jail cell, Langen told them that he had traveled there on a rod covered by ointment with a group of others where they spent the evening carousing. Langen woke up the following morning alone in the cell. Baffled, the authorities tried to convince him that he had made up the whole story.

But Langen persisted. He told the authorities that this was not that first time he had traveled on a rod covered by magical unguent. He had learned how to do this via three women, Catharin, Lisa, and Margareth. Together, they would smear their respective flying implements (sometimes shafts, other times pitchforks) with their ointment and travel to the houses of several beer brewers. Once there, they would help themselves to the brew.

This was no coerced confession extracted from a tortured man saying anything to overzealous inquisitors in hope of clemency; Langen's statements were all spontaneous. Interestingly, like Matteiccua di Francesco, Langen fit his knowledge of transvection ointments into an already made folk model. However, unlike Matteuccia, Langen did not fancy to travel to the walnut tree in Benevento. Instead, he fit his transvection experience into another already existing paradigm: that of the "folk of the keg."

Briefly, the folk of the keg seems to have been either a derivative or alternative or addition to (we really do not know) the general belief in fertility rites performed by nocturnal travelers believed to roam the towns and villages by moonlight. Sometimes these wandering hordes (called "barilotto" in Italian) would stop in houses with fully stocked wine cellars and help themselves to drink. It was not unlikely for this motley crew to then refill the wine casks with their urine (Bailey, 2013).
Langen's account does not fit any witch stereotype at all. Instead, it fits rather perfectly with known folk beliefs of the time. And the jailers seem to have lacked the theological training to fit Langen's story into conspiratorial notions of heresy or devil worship, as had been done to the folk of the keg in other instances when zealous theologians involved themselves in the proceedings (Mormando, 1999). They were merely baffled. Langen seems to have been nothing more than a lost soul who fell in with a small group that knew the occult use of soporific medical ointments to transvect (Bever, 2008). As for Hans Jacob Langen, the authorities beat the snot out of him and banished him from Lauffen for 3 years.

What I can gather so far is this: the magical ointments of regular people got caught up in a larger complex of theological ideas about witchcraft - ideas that only started to take shape toward the middle of the 14 th century. In the early modern and Renaissance periods, there seems to have been a general folk belief in fairy realms or dead societies overseen by a Fairy Queen or a Goddess or some kind of good mistress. This fairy realm went by a number of names depending on one's location in early modern Europe. For example, we read about "Elvenland" from British sources (Wenzel, 1989); Heuberg from Germanic sources (Hansen, 1901); and of the walnut tree of Benevento, Italy (Jansen et al., 2009). Reference to the realm even crops up in one famous (and tragic) trial - Joan of Arc was asked during her interrogation whether she personally (or knew of anyone that) "travelled through the air with the fairies" (Ginzburg, 1991). The so-called dead societies of medieval Europe also went by various names depending on location: the bona res, the game of the good society, Oriente's society, Wilde Jagd (the "wild hunt"), among many others (Ginzburg, 1991; Russell, 1984). And these various groups - those of the fairies and those of the dead - had enough in common that they started to overlap in clerical descriptions of them (Ginzburg, 1991). Perhaps it was this kind of realm (or something like it) that theologians bastardized into the satanic Sabbat?

I believe there exists good evidence to show that is exactly what happened.

\section{THE POST MODERN OINTMENT}

Up until the early 1970 s, scholars took seriously the reality of these ointments (Harner, 1973; Ostling, 2016). This would change with the publication of two more books: one released not long after those of Harrison and Harner; the other, just over a decade ago. First was Norman Cohn's Europe's Inner Demons (2000). Eschewing scholarly consensus, Cohn broke the mold and argued that the supposed psychedelic ointments of witches were complete fabrications by churchmen - nothing more than the ill fantasies of imaginative minds. Cohn outlines three problems with the claims made about these ointments. First, he says, not a single story about them comes from an eyewitness. Second, the earliest recipes from the 15 th century do not include anything psychedelic. Finally, many of the records indicate that the ointments were rubbed on "flying 
implements" like brooms, rakes, and shovels, and not the actual body (Cohn, 2000).

This last objection is true but, as we shall see, weightless.

The former two objections are demonstrably false.

To begin with Cohn's first point: that no eye-witness accounts survive that portray a person rubbing a psychedelic ointment on their flesh for transvection purposes. Granting the fact that rubbing one's genitals with a magical ointment was most probably a private affair, why would there be an eye-witness to this? How many eyewitnesses watched you put on your hemorrhoid cream last night?

This less-historical more practical observation aside, Cohn is still wrong. There are some eye-witness accounts. Alonso Tostado (1410-1455) claims to have witnessed a woman rubbing an ointment on her body that allowed her to transvect to some vague sybaritic affair (or so she believed; Hansen, 1901). Bernardino of Siena (1380-1444), while never claiming to have watched anyone rub one of these ointments on their body to fly, managed to inspect an ointment taken from one arrested healer, Finicella, who used the goop to turn into a cat. Or so she thought. Bernardino maintained that the ointment caused Finicella only to see her feline body in her mind (Robins, 1920). True, this is not a transvection ointment; but it implicates knowledge of a pythiagenic (e.g., "generating magic with psychedelics;" Hatsis, 2018) transformation ointment on the part of Finicella. Andres Laguna (1499-1559) even went so far as to carry out an experiment with these ointments on a woman suffering from insomnia. She slept for over $30 \mathrm{hr}$, and when she woke up told of participating in feasts and wild dancing. So sure was she of the reality of her experience, she felt the need to tell her husband that while at the banquet, she had fallen for a much younger and more attractive mate (Friedenwald, 1939). However, the single best eye-witness account can be found in The Book of Abramelin the Mage, written in the early 1600 s by Abraham of Worms. Therein, Abraham had been traveling across Europe, eventually spending some time in Linz, Austria. During his stay, Abraham meets a woman who assures him she can take him to a "town [he] wanted to visit." Curious of the nature of her powers, Abraham followed the woman to her dwellings where she presented him with her pythiagenic ointment. Lathering up the "arteries of [his] hands and feet," Abraham eventually fell into a deep, lucid dream state in which he "felt like [he] was journeying to the town which [he] in [his] heart wished to visit." When both he and the girl awoke, he determined that the ointment had been drugged, concluding that the experience was caused by nothing more than a "good and fantastic sleeping ointment that made all imaginations appear as realities" (Dehn, 2015).

So ... no eye-witness accounts?

As for Cohn's second claim - that the earliest recipes do not mention psychoactives - well, this is only partially true. Take Alonso Tostado: while recording his eye-witness account of a woman covering herself with a magical ointment, he does not give a recipe. He does, however, say that she used a kind of "medical ointment ... that causes the mind to detach from the body" ("... genus unctionis esse, quo tanta fit mentis alienatio et abstractio hominis a se ipso...") (Hansen, 1901, p. 109). Therefore, technically
Cohn is correct - there is no recipe here. But it is also true that Tostado is clearly referring to a psychoactive medical ointment - one that could be (mis)used for transvection (i.e., "mind detaching from the body"). And Johannes Nider's reports of these magical ointments offer the same: he does not give a recipe, but he does assure us that the ointment knocked the unholden out cold. He is clearly referring to a soporific ointment, possibly made of Solanaceae plants like henbane and mandrake (or even opiates), which cause deep, lucid dream states (Atkinson, 1887; Roberts \& Wink, 1998; Stephenson \& Churchill, 1831). Bernardino of Siena is clear that the ointment of Finicella caused her to envision that she had transformed into a cat (Robins, 1920), which, to me, suggests the presence of psychoactives. In Laguna's experiment, we actually know exactly the plants from which he concocted the ointment: hemlock, henbane, and deadly nightshade (Friedenwald, 1939). And, as we just saw a moment ago, while Abraham does not give us a recipe, he makes it clear that the "good and fantastic sleeping ointment" caused "all imaginations to appear as realities" (Dehn, 2015).

So yes, Cohn is correct - there are no early recipes for the ointment that include psychoactives before the mid-16th century. But all early references from the 1400s (specifically wherein the ointment is applied to the flesh) show rather conclusively that - exact recipes aside - there is every reason to believe that the ointments contained psychoactives.

As for Cohn's final claim, that the ointment was more likely rubbed on the flying implement and not the skin ... perhaps it is my limited training in the medical sciences, but I've never fully understood this objection. Even if a person only oiled up a flying instrument, they would still absorb the ointment. Hands are made of skin. Skin absorbs ointments. Hans Jacob Langen's candid testimony supports this method of ingesting the ointment. Furthermore, the earliest and best records (Nider, Tostado, Bernardino, and the trial of Matteuccia) hold the "witch" greasing up herself, not the flying implement.

The second book to disregard the historical reality of transvection ointments comes from our own psychedelic bard, Andy Letcher, in his eye-opening Shroom: A Cultural History of the Magic Mushroom (Letcher, 2007). However, his best assault comes at attacking not scholars of historical witchcraft but rather Margaret Murray and her book The Witch-Cult in Western Europe (1921). But Murray's knowledge (or lack thereof) regarding the relevant texts, languages, and cultural context of the witch trials was shallow at best (Cohn, 2000; Hatsis, 2015; Letcher, 2007). Moreover, the ointments did not occupy much space in The Witch-Cult in Western Europe. For Murray, the trips to the Sabbat were real events - the secret meetings of a transEuropean "witch-cult" (Murray, 1921). The need for a transvection ointment, by her logic anyway, was moot. And anyway, the real advocacy for the ointments in The WitchCult came not from Murray, but rather from her colleague, A. J. Clark, who appended a few recipes to later editions of her book. As scholars of witchcraft rightfully dismantled Murray's hypothesis - a hypothesis that had very little to do with transvection ointments - the transvection ointments unfairly went down with it. 
Letcher's lone reputable citation on this issue comes from Brain Levack's The Witch-Hunt in Early Modern Europe (Levack, 1995). Even still, Levack's sole argument rests in the fact that the ointment was more typically applied to the flying instrument, not the flesh. Therefore, he writes, we should take the ointments as "products of either harmless folklore or demonological theory, and not as effective mindaltering substances" (Levack, 1995). Besides the already stated physiological shortcoming with that objection, we still need an explanation for the early, eye-witness accounts that feature the "witch" rubbing the ointment on her flesh. We also need explanations for later cases, such as those of Abraham of Worms, Hans Jacob Langen, and Magdelena (although admittedly, her psychoactive concoction was bread, not an ointment).

A final note: Letcher doesn't account for the full breadth of Levack's thoughts on the matter. For earlier in The WitchHunt Levack also writes: "[I]t is quite possible that some of the witches who confessed to attending the sabbath either had experienced something like flight under the influence of drugs or had entered a deep, drug-induced sleep in which they had experienced fantastic or depressing dreams" (Levack, 1995). Although Levack has in recent years fully sided with the skeptics (Levack, 2016), I still find it interesting that this tidbit had been ignored in an otherwise monumental and important book. Like many of us who have wrestled with this question, Levack was of two minds regarding the ointments at the time he wrote The Witch-Hunt. Such is the complex nature inherent in the four histories I have tried to unpack in this short article.

One of the major shortcomings behind the post modern ointment is the insistence that - to borrow from Letcher (2007, p. 26) - "our views of the past are tempered by the attitudes and dispositions of the present [...] these views say more about us than they ever can about the people who came before us." While this is certainly true to some degree, as an all-encompassing rule, it does not pass muster. Letcher continues to write that the ointments represent just another example of the "utopian sentiment that accompanied the psychedelic revolution of the 1950s and 1960s" (Letcher, 2007, p. 26; also see Cohn, 2000). Nothing more. Perhaps, if Harner been the first academic to write about witches' flight and plant medicines, such an objection would have more weight. Unfortunately for the post-modernists, several authors wrote about the ointments before the "utopian sentiments" of the 1960s ever existed. Here are just a couple examples: was German toxicologist Louis Lewin simply pining for the summer of love of 1967 when he published Phantastica in 1924? Therein, Lewin writes about the use of Solanaceae plants in "magic ointments and witch philters" employed to, among other magical feats, participate in witch dances like those at the Brocken (another witch mountain like the Heuberg; Lewin, 1921). How could Lewin have known that LSD (which had not even been invented yet) would in just a few decades unleash its magic onto the streets of Europe and America? Or what about the Victorian anthropologist Edward Tylor? In 1871 Tylor wrote, "the medieval witch ointments ... brought visionary beings into the presence of the patient, transported him to the sabbat, enabled him to turn into a beast" (Tylor, 1920). Was Tylor a psychic? A proto-hippie?
Recently, professor of religious studies at Arizona State University Michael Ostling has attempted to discredit the reality of these psychoactive ointments in his piece "Babyfat and Belladonna" (Ostling, 2016). For Ostling, these ointments constitute nothing more than "imaginations caught up in the web of words and practices that constitute culture" (Ostling, 2016). Because Ostling's piece is the latest and most entertaining, a preliminary note of caution regarding his analysis need be addressed:

1. Ostling shows a lack of intimate knowledge with the relevant primary literature when he writes: "Early mentions of the witches' ointment do not connect it to flying at all" (Ostling, 2016, p. 42).

An interesting assertion, as the very first we hear of these magical ointments occurs in a trial record that connects it to flying - that of Matteuccia di Francesco (Jansen et al., 2009). And anyway - so what? Abraham of Worms' firsthand experience with a transvection ointment does not come from a trial record; and yet, it is difficult to deny the account's veracity (Dehn, 2015). And we cannot overlook the sleight of hand Ostling is playing with cases like Magdelena, so let us collectively acknowledge with a subtle eye-roll that her transvection bread wasn't technically a transvection ointment. Additionally, I find it far more important that early commentators like theologians Johannes Nider and Alonso Tostado discuss transvection ointments outside any trial record - instead, we get candid commentaries on folk beliefs and uses with them (Hansen, 1901).

2. Ostling also shows a willingness to misquote or bend the evidence and even fabricate opinions presented in secondary source literature.

Take renowned scholar of micro-history Carlo Ginzburg, who Ostling claims "dismiss [es] the phytochemical approach in a footnote" (Ostling, 2016). Here, Ostling refers to statements made in Ginzburg's The Night Battles (Ginzburg, 1992). But this completely misrepresents Ginzburg's thoughts on the matter. What Ginzburg actually states in the footnote Ostling cites revolves around two modern experiments with psychoactive ointments, one of which concluded with "a simple headache," the other concluded with "hallucinations that resembled perfectly those described in witchcraft trials" (Ginzburg, 1992). This is hardly a dismissal. The two experiments merely showed the need for proper set and setting when using plant medicines. Perhaps most telling, the sentence following the one Ostling cites from The Night Battles reads: "It seems reasonable to suppose, nevertheless, that if not all, at least some of the accused witches, used unguents capable of inducing states of hallucination and delirium" (Ginzburg, 1992, p. 17).

It is amazing what one chooses not to see or report.

The problems continue to mount. For Ostling also claims that Hans Peter Duerr explains away the lack of mention about psychoactive ingredients in trial records in an "ingenious" way: "true witches preferred to die at the stake than give up their secret recipes, while the church sedulously suppressed any hints of such salves as [they] made their way into the records" (Ostling, 2016, p. 50). Let us explore each of these points in turn. Does Duerr really believe that keepers of occult herbal knowledge would rather die than reveal their secrets? Certainly not. Duerr never wrote anything of the sort. 
And with good reason. Duerr's take on the ointments is far more balanced - even criticizing Harner (among others) for overstating the role of psychedelics in early modern witchcraft (Duerr, 1985)! The idea is both absurd and insulting to those poor, tortured women who did not have a choice which is why Ostling wants you to think Duerr believes it. It is an odd form of ad hominem wherein Ostling does not attack Duerr's character, but rather suggests that Duerr believes something we would all find repugnant. It is now our job (so hopes Ostling) to attack Duerr's character over this false allegation.

As to the second point - whether or not "the church" suppressed any hints of psychoactives in the ointments. Again, Ostling is not treating Duerr fairly - the latter's argument is far more complex than that. What Duerr does say is that some religious and secular authors downplayed the psychoactives in the ointments because such natural explanations rendered "The Devil ... with only a very modest significance, or none at all" (Duerr, 1985, p. 4). Duerr cites Reginald Scott, Parliament member and author of the skeptical The Discovery of Witchcraft (1584), who sought to show that witchcraft and magic were shams. And Duerr has a point. For Scott was certainly knowledgeable of "hearbs and stones found and knowne to the physicians, which maie procure dreames; and other hearbs and stones [and company] to make one bewraie all the secrets of his mind. ... But that witches or magicians have power by words, herbs [sic], or imprecations to thrust into the mind or conscience of man ... by vertue of their charms, hearbs, stones, or familiars ... I denie" (Scott, 1972, p. 103). For Scott it was not the hearbs, stones, and other magical accoutrement that caused these visions, but rather "that the divell ... travelleth to seduce man, and to lead him from God" (Scott, 1972, p. 103).

Duerr is further supported by 15 th century demonologist Jean Vincent who accepted the psychoactive nature of the ointments, but downplayed their role in lieu of demonic powers:

Wise-women skilled with plants [venefici] ... mix pharmaka into love potions and ointments which cause bizarre psychological reactions, transformations, but usually end up killing the user. [These women] claim to be transported far away at night to demonic Sabbats by using the aforementioned pharmaka. The correct deduction, however, is that none of these [magical feats] should be attributed to the natural powers found in the pharmaka, but instead to a shrewd demon ... who is the primary operative cause; [whereas] the pharmaka is only the secondary cause. (Hansen, 1901, pp. 229-230)

And of the ointments' effects? Vincent says it is similar to the effects of drinking wine laced with mandrake. "Venenis igitur utuntur venefici pariter et poculis quibusdam atque unguentis, quibus humanas mentes perturbant, corpora alterant et plerumque homines interficiunt. Horam eciam venenorum virtute per noctes se dicunt ad sabbata longe remota demonum portari. Que tanem singular recte iudicanti naturali non sunt virtuti alicui talium venenorum attribuenda, sed magis fallaci astucie demonis, qui huismodi unguentorum linitionibus aut poculorum exhaustionibus ex pacto cum primis huius damnatu artis inventoribus expresse inito assistit et illa, que virtute predictorum fieri creduntur, ipse demon applicando active passivis operator, qui causa principalis est et effective, huismodi vero venena per maleficis adhibita causa sunt, sine qua non fierent ista"; "... mandragore cortcem cum vino mixtum ad bibendum" (Ibid, pp. 229-230). Or, we can revert back to Matteuccia's case. The record indicates that Matteuccia believed her ointment held the power of transvection. However, Novello Scudieri, the notary who penned Matteuccia's confession, would have us believe that a demon really carried her away (more on this below; Jansen et al., 2009).

In an ironic twist, popular with post modernists, Ostling already concurs with Duerr's point, even as he argues against it - insightfully acknowledging that the focus of the transvection ointments by early writers was less about flying and far more about "the murder of children as emblematic of witches' depraved monstrosity" (Ostling, 2016).

I could not agree more with Prof. Ostling. I would just add that the psychoactive plant materials also were not the focus of these early records.

To conclude on Ostling's treatment of Duerr: he made up the first part and failed to acknowledge the evidence that supports the second part, including his own astute observation.

Finally, Ostling did himself no service by inventing a quote out of whole cloth and placing it on the pen tip of yours truly while reviewing my book, The Witches' Ointment (Ostling, 2017). To be fair to Ostling, his forged words deal not with transvection ointments, but rather with my opinions regarding the possible use of psychoactive potions by a 2nd century Gnostic-magician named Marcus. Therein, Ostling cites me as writing on page 52 of my book, "Marcus and his group used psychoactive love-potions consensually for erotic entheogenic magic" (Ostling, 2017 , p. 273). That line does not appear anywhere in my book - on page 52 or otherwise. Much like Duerr's supposed theory that witches would rather die than reveal how the ointments were concocted, Ostling made this up too. What I do write about Marcus is this: "To someone like Irenaeus [Church Father who condemned Marcus] all such magical practices were not only illegal but also immoral meaning we can't be certain how Marcus really used his potions" (Hatsis, 2015, p. 58). I left the question open - not once saying anything as definitive in The Witches' Ointment about Marcus's potions as Ostling would have one believe. Ostling simply fabricated a quote that says the opposite of what I wrote.

Ostling's need to cherry-pick and obfuscate Ginzburg's, Duerr's, and my true thoughts on these matters only raises interesting questions about why such tactics would be necessary. It also calls into question how thoroughly the review board at the publishing journal, Magic, Ritual, and Witchcraft is fact-checking Ostling's claims - especially claims that distort the historical reality of transvection ointments.

Putting all this aside, the larger post-modernist interpretation still falls short by failing to address two crucial points: first, this perspective never addresses why either 
demonologists or naturalists would need to invent these ointments to explain transvection in the first place. This objection is important for at least two reasons: (a) Stories of spiritual journeys had existed for centuries. In nearly every case, an ointment is not mentioned as necessary (or simply not recorded). (b) In some cases from the early to mid 14th century (as the witch stereotype was taking shape) some "witches" were said to fly without the use of magical ointments at all (Hansen, 1901). Medieval and early modern European cultures were ripe with stories of night travelers, spirit projectors, and the like, and rarely (if ever) does an ointment come into the picture. There really was not much of a need to invent a magical ointment for such purposes. People were doing all these things without them. Therefore, we should take people at their word when we hear about them using transvection ointments (or breads), especially in cases where no torture was used (Abraham of Worms, Magdalena, and Hans Jacob Langen), as well as in cases where the transvection ointment fit into folk beliefs, not theological stereotypes (the latter two plus Matteuccia di Francesco).

Second, the post-modernist interpretation overlooks the fact that some of the first real mentions of these ointments do not tie them to diabolical witchcraft at all! Here, I refer back to the accounts of Nider and Tostado. While Tostado would later demonize the ointments, both men introduce the salves into history without any satanic witchcraft baggage whatsoever. In fact, Nider wrote about the ointments twice and did not associate them with diabolical witchcraft either time. Furthermore, it is clear that he knew of other magical ointments and potions that were used in diabolical witchcraft (or so he'd heard); in Formicarius he recalls a story told to him by inquisitor Peter of Greyerz. According to Greyerz, a group of heretics living in Simmental, Switzerland, around the 1390s used the blood of infants to compose ointments for their "arts and transmutations" ("... De solidiori huius materia unguentum facimus nostris voluntatibus et artibus ac transmutationibus accomodatum." Hansen, 1901, p. 93). And yet, Nider never associates the unholden's transvection ointment with the unholy ointments supposedly used in diabolical witchcraft, the latter obviously culled from the heretical stereotype. The former appears in Book II, "On False Dreams and Revelations;" the latter, in Book 5, "On Witches." They are still two different things (Hansen, 1901; Nider, 1475). Bernard of Como, writing almost a century after Nider, differentiated between "the strigas sect" and those of "the pagan goddess" - even if many of his colleagues did not (Duerr, 1985). Finally, what Nider's chapter shows is that the use of an ointment to achieve revelations (albeit "false" revelations in Nider's eyes) was just one of many protocols employed by common people.

Where the post modern ointment might have had some merit would have been found in the record of Matteuccia di Francesco, in which authorities absolutely tied her magical transvection ointment to diabolism (Jansen et al., 2009). Her trial predates both the writings of Nider and Tostado, which could add more weight to the post-modern interpretation. However, there is a slight hiccup: for buried in the dossier sit little clues for the careful investigator to untangle. Matteuccia's record exists in two spheres - the first part of the document charges allegations of folk remedies and love magic; the second part of the document waxes diabolical witchcraft accusations.

And the turning point in the record that bridges the two spheres together?

You guessed it: Matteuccia's magical transvection ointment that brought her to the Night Doings at the walnut tree of Benevento.

Looking deeper we see that the ointment does not just bridge the two spheres of the record but exists in two spheres as well. As we saw earlier, Matteuccia's record combines both folk beliefs (transvection and animal transformation) and theological stereotypes (demonism). Similarly, we can quite literally tease out Matteuccia's probable genuine folk beliefs about her ointment from the theologically contrived, literary traditions of yore plastered over it. For example, the first part of this section of the record holds Matteuccia rubbing the unguent on her body as she sings "Ointment, ointment, bring me to the Night Doings at Benevento, over water, over wind, over all bad weather" (Jansen et al., 2009). This does not belong to any theologically derived fantasy. This appears to be authentic psychedelic history. Let us note that Matteuccia placed the transvection powers squarely on the ointment.

However, the record does not stop there, for Matteuccia continues her chanting, "Oh Lucibel, demon of hell, after you were released you changed your name and have the name of Great Lucifer, come to or send me one of your servants" (Jansen et al., 2009). Here is the witch stereotype forced into her mouth by zealous bastards under torturous conditions.

Novello Scudieri tells us that the ointment was made of vulture and owl blood (probably true), the blood of infants (highly doubtful), and other ingredients (though he fails to tell us more about them). I believe those other ingredients were probably psychedelic - or more accurately somnitheogenic - in nature.

There were at least three reasons for Scudieri to ignore any possible psychoactive ingredients in the ointment. First, as Ostling correctly points out, authorities tended to focus on the depravity of harming and killing infants, first and foremost. Or, second, like physician Johannes Weyer (1515-1588) and historian Richard Rudgley, Scudieri might have feared that releasing such information would encourage others to try these psychoactive ointments themselves (Mora et al., 1991; Rudgley, 1998). Finally, Scurideri might have simply prefigured men we have already met like Jean Vincent and Reginald Scott who both argued that the psychoactives in the ointments took a backseat to the power of demons or even the Devil himself (Hansen, 1901; Scott, 1972).

I tend to side with those who believe the ointments represent just a small part of a larger magical cultural complex (Bennett, 2018; Bever, 2008; Harner, 1973). The two earliest mentions of these ointments, I think, demonstrate this. The unholden in Predigten and Matteuccia (without the stereotypical diabolical dress) show inferences to folklore: some kind of belief, whether spiritual or otherwise, accessed through a variety of means (including somnitheogenic ointments), wherein a person transvects to some distant place ruled by some kind of Goddess or Fairy Queen. She was first turned into "Diana" and then turned 
into Satan. Alonso Tostado is quite clear on this matter. While reflecting on whether or not people could use magical ointments to transvect, he states bluntly, "... they believe Diana is a goddess and yet she is the Devil" ("Hoc autem est, quia credunt Dianam deam esse, et tamen Diana est diabolus") (Hansen, 1901, p. 108). He seems to have changed his mind on the ointments after the proper formulation of the witch stereotype (Hatsis, 2015, 2018).

Other attempts to discredit the reality of transvection ointments fair no better. As Edward Bever notes, "Some historians downplay or even deny these drugs any role in the history of witchcraft, pointing to the frequency with which unguents brought forward in trials were found to be inert" (Bever in Golden, 2004, p. 297). Usually, these skeptical historians are referring to the witchcraft investigations undertaken in Basque between 1609 and 1614 by Alonso de Salazar Frías, the "witches' advocate" of the early 17th century (Henningsen, 1980; Ostling, 2016). Salazar weighed evidence in a doggedly conservative manner, not given to fanciful notions of diabolical activity without hardcore proof. And so it happened that during his investigation he had 22 jars of ointments given to him by accused "witches" tested for contents by various doctors and apothecaries. By the time 16 of the 22 results had came back, Salazar thought it expedient to inform the inquisitor general of the situation: "Not a single one out of the sixteen jars I have discovered to date seems traceable to the [witches' ointment; i.e., none are psychoactive]" (Henningsen, 1980). The remaining six also proved to contain nothing psychoactive.

I'm not so sure why this episode matters in light of the real evidence. No one (certainly not me) argues that all ointments from the early modern and Renaissance eras were psychoactive. And we ought not to think of psychoactive ointments as the only kinds that were considered magical. Indeed, Ostling has done a superb job showing the variety of innocuous folk ointments wielded by any number of persons (Ostling, 2016). It is a point I have made myself; when psychoactive preparations do appear in medieval and early modern literature, they sit alongside - and are grossly outnumbered by - decidedly non-psychoactive (though equally magical) preparations (Hatsis, 2015). As just one example, in 1404 the Florentine courts found Jacopo di Francesco guilty of using a magical sex unguent made out of the brains of a raven mixed with honey (Brucker, 1971). Furthermore, skeptics overlook something crucial about the Basque affair: those accused women were most emphatically not the kinds of people like Matteuccia or Finicella (or even the three women from whom Langen learned the powers of transvection ointments) that knew the occult virtues of psychoactive plants. As historians have long recognized, the majority of people burned for witchcraft knew nothing of witchcraft - unfortunate souls unfairly caught up in mechanisms beyond their control or understanding (Cohn, 2000; Duerr, 1985; Keickhefer, 1976). Therefore, it is not surprising that the Basque defendants simply concocted the ointments out of whatever they had available to them to satisfy their prosecutors (Henningsen, 1980). After all, they were promised leniency for complying. What else should they have done? To claim that the reality of non-psychoactive ointments proves the unreality of psychoactive ointments seems shortsighted.
We must also remember to mark the experience of de Salazar Frías against that of Andres Laguna who found a jar of ointment in a house occupied by two hermits accused of witchcraft. This ointment contained deadly nightshade, hemlock, and henbane, which is why Laguna, as we saw earlier, composed his ointment from those plants in the first place.

A final note on the post modern ointment - it seems this perspective appeals not just to post-modernist historians, but to some modern witches as well. Gerald Gardner (1884-1964), founder of Gardnerian Witchcraft, dismissed the historical probability of transvection ointments for a single reason: he did not know any witches who used them; therefore, they could not possibly have existed at any point in history. Truly a solid refutation! Gardner's two explanations for the myriad references to these ointments in early modern sources leave much to be desired, for he claims: (a) Witches used the ointments to protect their naked bodies from the cold during their outdoor rituals. (b) Witches covered themselves with ointments to make themselves more slippery, and therefore more difficult to apprehend by the authorities if caught while practicing their craft (Penicka, 2004); I can find no mention of either of these possibilities in any of the primary or secondary source literature - notwithstanding Gardiner. And with good reason: they both make no sense.

\section{PERACTIO}

While Harner fell short of applying critical historical methods to his claims, and so overlooked the various European cultural backgrounds into which people fastened transvection ointments, he was certainly correct (in my opinion) in a broad sense: early modern people used these kinds of psychoactive mixtures to achieve forms of what we would call astral projection, both secular (Abraham of Worms and Hans Jacob Langen) and sacred (like, I believe, Matteuccia). Unfortunately, his contribution also came with a hump in popular culture. And of the broom-flying, Satan-worshiping witch of popular imagination? - she was created by authorities (both secular and religious) in the early to mid 15 th century (Cohn, 2000; Keickhefer, 1976; Levack, 2016; Russell, 1984). Postmodernist deconstructions of the ointments serve to remind us that we do not know the whole story, while also showing the shortcomings of post-modernist deconstructions (Letcher, 2007; Ostling, 2016).

We are left with the most probable explanation: the application of an ordinary soporific unguent, available at any apothecary, used as a way to experience witch dances, nocturnal soirées with fairies and goddesses, animal transformations, or even parties in jail cells. For even if conservative and postmodernists historians alike are correct, and the transvection ointment was dreamed up by theologians in the early 1400 s, we still see clear evidence for its use in the 1600s (Abraham of Worms, Hans Jacob Langen or even Magdelena's magic bread). Perhaps, there is some middle ground there after all?

But if we look deeper and wrestle with what these ointments might have meant to some of the people using them, we raise interesting questions in the psychedelic Renaissance. Consider this: if these kinds of entheogenic 
lineages protect members of the Native American Church against laws governing peyote use, should not these same protections cover, say, a contemporary believer in the Great Goddess of yore who prefers entheogenic sacraments? Presuming the unholden that Nider describes was exactly that - a worshiper of Holda - what does it say about her transvection ointment? And what of those pagans of Cyprus, described by the Dominican theologian Felix Faber (mid 15 th century), who reveled in their worship of both Venus and Adonis inside a mountain cave? There, a garden had been sown with "lust making plants" (Faber, 2012), perhaps including mandrake, which according to the Renaissance magician and alchemist Agrippa (1486-1535) was still used as a psychoactive aphrodisiac around that time (Dunn, 1974). If these experiences constituted spiritual rites what does that say about the legal standing of these religious lineages? What of contemporary healers who, like these early modern wise-folk, gain insight by connecting to some kind of higher "source" via plant teachers - no matter what the cultural specifics of such a concept implies? What of the thousands of people rotting in prison for cannabis, mushroom, and other psychedelic use? Will they do nothing more than serve as a reminder of how important spiritual and cognitive liberties remain? We have already seen how ugly this kind of repression can get when taken to the extreme the charred souls of roughly 40,000 people still echo through the centuries. Authoritarians, conservative scholars, and post modernists alike have distorted and all but tried to erase this chapter from the annals of psychedelia.

And that is why it is so important that we get the history right.

Conflict of interest: The author declares no conflict of interest.

\section{REFERENCES}

Adler, M. (1986). Drawing down the moon: Witches, druids, goddess-worshippers, and other pagans in America today. Boston, MA: Beacon Press.

Alm, T. (2003). The witch trials of finnmark, Northern Norway, during the 17th century: Evidence for ergotism as a contributing factor. Economic Botany, 57(3), 403-416. doi:10.1663/ 0013-0001(2003)057[0403:TWTOFN]2.0.CO;2

American Bible Society. (1989). Holy Bible. New revised standard edition. New York, NY: American Bible Society.

Atkinson, A. (1887). Clinical studies on Hyoscyamia. Journal of Materia Medica, 25(7), 102-105.

Bailey, M. (2013). Nocturnal journeys and ritual dances in Bernardino of Siena. Magic, Ritual, and Witchcraft, 8(1), 4-17. doi:10.1353/mrw.2013.0013

Behringer, W. (2005). How waldensians became witches: Heretics and their journey to the other world. In G. Klaniczay \& É. Pócs (Eds.), Communicating with the spirits (Vol. I). New York, NY: Central European University Share Company.

Bennett, C. (2018). Liber 420: Cannabis, Magickal herbs, and the occult. Walterville, OR: Trine Day.
Bever, E. (2008). The realities of witchcraft and popular magic in early modern Europe: Culture, cognition, and everyday life. New York, NY: Palgrave Macmillan.

Bouquet, M. (1760). Recueil des historiens des Gaules et de la France [Collection of the historians from Gaul and France]. Paris: Aux Depens des Libraires Associes. Retrieved from archive.org

Bramshaw, V. (2009). Craft of the wise: A practical guide to paganism and witchcraft. Winchester, UK: O Books. OBE.

Brehaut, E. (1916). History of the franks. New York, NY: Columbia University Press.

Brucker, G. (1971). The society of Renaissance Florence: A documentary study. New York, NY: Harper and Row.

Butler, R. R. (Trans.). (1842). Annales Hiberniae. Dublin: Graisberry and Gill.

Cohn, N. (2000). Europe's inner demons. Chicago, IL: The University of Chicago Press.

Dehn, G. (Trans.). (2015). The book of Abramelin: A new translation. Lake Worth, FL: Ibis Press.

Devereux, P. (2008). The long trip. Brisbane, AU: Daily Grail Publishing.

Duerr, H. P. (1985). Dreamtime. Oxford, UK: Basil Blackwell Ltd.

Dunn, C. (Ed.). (1974). Of the Vanitie and uncertainties of arts and sciences. Northridge, CA: California State University Foundation.

Faber, F. (2012). Evagatorium in Terre Sanctce, Arabice et Egypti [Evagatorium in the land of women, Arabia and Egypt] (Vol. I). Facsimile, Nabu Press.

Friedenwald, H. (1939). Andres Laguna: A pioneer on his views of witchcraft. Bulletin on the History of Medicine, 7, 1037-1048.

Gannon, M. (2013). A bewitching history: Why witches ride broomsticks. Retrieved from https://www.livescience.com/ 40828-why-witches-ride-broomsticks.html

Ginzburg, C. (1991). Ecstasies: Deciphering the witches' Sabbath. New York, NY: Pantheon Books.

Ginzburg, C. (1992). The night battles: Witchcraft and agrarian cults in the sixteenth and seventeenth centuries. Baltimore, MD: Johns Hopkins University Press.

Golden, R. (2004). Encyclopedia of witchcraft: The western tradition. Santa Barbara, CA: ABC-CLIO.

Hansen, J. (1901). Quellen und untersuchungen [Source and investigations]. Bonn, Germany: C. Georgi.

Harms, D., Clark, J. R., \& Peterson, J. H. (2015). The book of Oberon: A sourcebook of Elizabethan magic. Woodbury, MN: Llewellyn Publication.

Harner, M. (1973). The role of hallucinogenic plants in European witchcraft. In M. Harner (Ed.), Hallucinogens and shamanism. New York: Oxford University Press.

Harrison, M. (1973). The roots of witchcraft. New York, NY: The Citadel Press.

Hatsis, T. (2015). The witches' ointment: The secret history of psychedelic magic. Rochester, VT: Park Street Press.

Hatsis, T. (2018). Psychedelic mystery traditions: Spirit plants, magical practices, ecstatic states. Rochester, VT: Park Street Press.

Henningsen, G. (1980). The witches' advocate: Basque witchcraft and the Spanish inquisition. Reno NV: University of Nevada Press.

Highfield, R. (1999). The physics of Christmas. New York, NY: Back Bay Books. 
Holinshed, R. (1587). The chronicles of England, Scotland and Ireland. London, UK: Printed by Henry Denham, at the expense of John Harrison; accessed via: Schoenberg Center for Electronic Text and Image; University of Pennsylvania Libraries.

Hoyt, C. A. (1989). Witchcraft. Carbondale, IL: Board of Trustees, Southern Illinois University.

Irvin, J., \& Rutajit, A. (2009). Astrotheology and shamanism: Christianity's pagan roots. Garden City, NY: Gnostic Media.

Jacques, J. H. (1970). The mushroom and the bride. Derby, UK: The Citadel Press.

Jansen, K. L., Drell, J., \& Andrews, F. (2009). Medieval Italy: Texts in translation. Philadelphia, PA: University of Pennsylvania Press.

Johnson, C. (2018). Retrieved from psychedelicfrontier.com

Keickhefer, R. (1976). European witch trials: Their foundations in popular and learned culture 1300-1500. Berkeley, CA: University of California Press.

Klaniczay, G., \& Pócs, E. (2005). Communing with the spirits: Demons, spirits, and witches (Vol. I). New York, NY: Central European University Share Company.

Kors, A., \& Peters, E. (trans.). (2001). Witchcraft in Europe 400-1700: A documentary history. Philadelphia, PA: University of Pennsylvania Press.

Letcher, A. (2007). Shroom: A cultural history of the magic mushroom. New York, NY: HarperCollins.

Levack, B. (1995). The witch-hunt in early modern Europe (3rd ed.). New York, NY: Routledge.

Levack, B. (2016). Afterword. Magic, Ritual, and Witchcraft, 11(1), 109-116. doi:10.1353/mrw.2016.0001

Lewin, L. (1921). Phantastica. Rochester, VT: Park Street Press.

Major, J. (1892). John major's history of greater Britain as well as England and Scotland. Edinburgh, UK: University Press.

McKenna, T. (1992). Food of the Gods. New York, NY: Bantam.

Monter, W. (1976). Witchcraft in France and Switzerland: The borderlands during the reformation. New York, NY: Cornell University Press.

Mora, G., Kohl, B., Shea, J., Weber, J., Midelfort, E., \& Bacon, H. (1991). Witches, devils, and doctors of the Renaissance: Medieval and renaissance texts and studies 73. Binghamton, NY: State University of New York Center for Medieval and Early Renaissance Studies.

Mormando, F. (1999). The Preacher's demons: Bernardino of Siena and the social underworld of early Renaissance Italy. Chicago, IL: University of Chicago Press.

Müller, J. L. (1998). Love potions and the ointment of witches: Historical aspects of the nightshade alkaloids. Clinical Toxicology, 36(6), 617-627. doi:10.3109/15563659809028060

Murray, M. (1921). The witch-cult in western Europe. Oxford, UK: Claredon Press.
Nider, J. (1475). Formicarius: Dialogus ad vitam christianam exemplo conditionum Formice. Cologne, Germany: Ulrich Zell.

Ostling, M. (2016). Babyfat and Belladonna: Witches' ointment and the contestation of reality. Magic, Ritual, and Witchcraft, 11(1), 30-72. doi:10.1353/mrw.2016.0008

Ostling, M. (2017). Review of Hatsis the witches' ointment. Magic, Ritual, and Witchcraft, 12(2), 271-274. doi:10.1353/ mrw.2017.0031

Penicka, S. (2004). Caveat Anoynter!: A study of flying ointments and their plants. In C. Hartney \& A. McGarrity (Eds.), The dark side: Proceedings of the seventh Australian and international religion, literature and the arts conference 2002 (pp. 181-195). Sydney, Australia: RLA Press.

Peters, E. (1982). The magician, the witch, and the law. Philadelphia, PA: University of Pennsylvania Press.

Pico della Mirandola, G. F. (1523). Dialogus Strix: sive de Ludificatione Daemonum [A discussion on witches: Or the demon's game-maker]. The Bavarian State Library. Retrieved from books.google.com

Roberts, M., \& Wink, M. W. (Eds.). (1998). Alkaloids: Biochemistry, ecology, and medicinal applications. New York, NY: Plenum Press.

Robins, H. (Trans.). (1920). Saint Bernardino of Siena: Sermons. Siena, Italy: Tipografia Sociale.

Rudgley, R. (1998). The alchemy of culture. London, UK: British Museum Press.

Russell, J. B. (1984). Witchcraft in the Middle Ages. Ithaca, NY: Cornell University Press.

Scott, R. (1972). The discoverie of witchcraft. New York, NY: Dover Publications.

Shaw, N. (2016). Otherworld Gnosis: Fairy ointments and the nuts of knowledge. Psychedelic Press UK, 17, 41-53.

Shultes, R. E., \& Hofmann, A. (1992). Plants of the Gods. Rochester, VT: Healing Arts Press.

Sidky, H. (2010). Witchcraft, lycanthropy, drugs, and disease. Eugene, OR: Wipf and Stock.

Stephenson, J., \& Churchill, J. M. (1831). Medical botany. London, UK: John Churchill.

Tylor, E. (1920). Primitive culture (Vol. II). London, UK: John Murray.

Wenzel, S. (Ed. and trans.). (1989). Fasciculus morum: A fourteenth-century Preacher's handbook. University Park, PA: Pennsylvania State University Press.

Whiston, W. (1737). The genuine works of Flavius Josephus the Jewish historian. London, UK: University of Cambridge. Retrieved from penelope.uchicago.edu/josephus/index.html

Wright, T. (2012). Chapters in the history of sorcery and magic. In T. Wright (Ed.), Narratives in sorcery and magic: From the most authentic sources (Vol. I). London, UK: Cambridge University Press. 